\title{
PROFESSOR BONNEY AND THE LATE COLONEL GEORGE GREENWOOD.'
}

Sre,-In justice to the memory of one who has been long departed, but a former writer in the Geological Magazine, I trust you will allow me to enter a strong protest in your pages against the manner in which Professor Bonney has treated the work of my uncle, the late Colonel George Greenwood, in the book he has recently published under the title of The Work of Rain and Rivers, one of the Cambridge Manuals of Science and Literature.

Colonel George Greenwood published his work, Rain and Rivers, in 1857 , at a time when geological opinion had by no means emancipated itself from the doctrines and dogmas of the cataclysmic and catastrophic school. He was one of the very first to argue in support of the "doctrine of continuity", maintaining that the present aspect of the globe is due to causes still at work, and which have been acting for an immeasurable period of time. He was, in fact, a pioneer of the doctrine of "evolution in the organic world". It was, therefore, with great appropriateness and entire justice that the late Mr. Mackintosh styled him "the father of modern sub-aerialism" (Geot. MaG., 1876, p. 572).

I maintain, therefore, that Colonel George Greenwood is entitled to very honourable mention in the history of geological thought. But how is he treated by Professor Bonney? The Professor first damns him with faint praise, and then dismisses him with a quotation from some unknown 'reviewer' in the Geological Magazine of 1867 (p. 412). Professor Bonney, on p. 132, further says : "It was not until 1862 that the work of rivers in the excavation of valleys was placed beyond question in our own country. For this we are indebted to ...J. B. Jukes ..." I should be the last to underrate the debt which is owing to the memory of Mr. Jukes, but what did Professor Jukes say himself in 1863 of Colonel Greenwood's book? He alludes to it as "an excellent little work called Rain and Rivers . . . in which the atmospheric origin of all river valleys is advocated in the clearest and most convincing style".

In view of all this (and much more evidence to the same effect could be adduced). I venture to say that Professor Bonney does very great injustice to the memory of the author of a most clearly reasoned and original work. I can only appeal to you, sir, in the interest of historical accuracy, to gire this letter a place in the Grologicar. Magazine, and to Professor Bonney to eliminate a passige as ungenerous as it is unjust from the second edition of his Manual. Meanwhile, if this letter could but induce some geological students of to-day to read for themselves the pages of Rain and Rivers, they will, I am confident, recognize the justice of the claim which I make on behalf of a remarkable book.

George Greenwood.

House oF Commons.

November 19.

1 [Owing to want of space it has been found necessary to greatly abridge Mr. Greenwood's letter.-ED. GEOL. MAG.] 